\title{
Estimation of carbon stocks in a beech forest (Fougères Forest - W. France): extrapolation from the plots to the whole forest
}

\author{
Sandrine LECOINTE ${ }^{\mathrm{a}}$, Claude NYS ${ }^{\mathrm{b} *}$, Christian WALTER $^{\mathrm{c}}$, Françoise FORGEARD ${ }^{\mathrm{a}}$, Sandrine HuET ${ }^{\mathrm{a}}$, \\ Paula RECENA ${ }^{\mathrm{c}}$, Stéphane FOLLAIN ${ }^{\mathrm{c}}$ \\ a Université de Rennes I CNRS IFR Caren, UMR 6553 «Ecobio », Campus de Beaulieu, 35042 Rennes Cedex, France \\ ${ }^{\mathrm{b}}$ Unité de Biogéochimie des E cosystèmes Forestiers, INRA, Centre de Nancy, 54280 Champenoux, France \\ c UMR 1069 INRA/ENSA, INRA SAS, Centre de Rennes, 65 route de St Brieuc, 35042 Rennes Cedex, France
}

(Received 30 March 2005; accepted 25 October 2005)

\begin{abstract}
The Kyoto Conference identified the need to establish an accurate inventory of carbon stocks in forests. Carbon stocks were estimated in a beech forest (Fougères forest - France) using a combination of in situ field samples with existing soil and vegetation maps. Soil, humus and vegetation stocks were measured at 100 sampling points distributed throughout representative classes within the entire forest massif. Carbon levels in the soil and humus were determined in the laboratory; models predicting the biomass were used to estimate the stocks in the vegetation. From the statistical analyses and existing maps these point data were extrapolated to the whole forest using two changes of scale. The total carbon stock was estimated to lie in a range between 442200 and 505105 tC (a difference of 15\%). Half of the carbon stock was found in the soil, $45 \%$ in the vegetation and $5 \%$ in the humus. To evaluate the accuracy of this estimate, possible sources of error were examined and quantified. The carbon stocks in the vegetation were the most variable. Nevertheless, the results are likely to be integrated into future forest management plans and generalised in other contexts to evaluate carbon stocks at a regional scale.
\end{abstract}

carbon stocks / forests / Fagus sylvatica / scale change / soil / humus / vegetation

Résumé - Estimation du stock de carbone dans une hêtraie (forêt de Fougères, Ouest de la France) : extrapolation de la parcelle au massif. La conférence de Kyoto a révélé le besoin d'établir un inventaire précis des stocks de carbone en milieux forestiers. Les stocks de carbone ont été estimés dans une hêtraie (forêt de Fougères, France) en combinant un échantillonnage sur le terrain avec des cartes existantes du sol et de la végétation. Les stocks de carbone dans le sol, les humus et la végétation ont été mesurés sur 100 points distribués dans les classes représentatives de l'ensemble du massif forestier. Les teneurs en carbone dans le sol et les humus ont été déterminées par analyses au laboratoire. Pour la végétation, des modèles de biomasse carbonée établis dans divers peuplements du massif ont ensuite été utilisés pour les autres peuplements. Après analyse statistique de la variabilité, et sur la base des cartes disponibles, les valeurs des stocks de carbone ont été extrapolées à l'ensemble du massif forestier en utilisant deux changements d'échelle. Le stock total de carbone a été estimé dans une fourchette entre 442200 et 505105 tC (un écart de $15 \%$ ). La moitié du stock de carbone se trouve dans le sol, $45 \%$ dans la végétation et $5 \%$ dans les humus. Pour évaluer la qualité de ces estimations, les sources d'erreurs ont été examinées et quantifiées. La variabilité est la plus élevée dans le compartiment de la végétation. Cette démarche devrait être généralisée à d'autre conditions écologiques afin d'améliorer l'estimation des stocks de carbone de la forêt française.

stocks de carbone / forêts / hêtre / changement d'échelle / sol / humus / végétation

\section{INTRODUCTION}

Atmospheric $\mathrm{CO}_{2}$ concentration increased by about $9 \%$ between 1971 and 1990 and will probably have doubled by the end of the 21 st century, mainly due to man-made emissions [26, 30]. This increase results in global climatic warming considered by the Rio summit in 1992 to be dangerous. The capacity of terrestrial ecosystems to act as carbon sinks could partly compensate for the increase in atmospheric $\mathrm{CO}_{2}$ concentrations. Forest ecosystems only cover $30 \%$ of the land areas, but contain $81 \%$ of the terrestrial carbon biomass [15]. In addition, forests accumulate 20 to 100 times as much carbon per unit area as agricultural land and are 20 times more productive than grassland $[11,18]$. The need for an accurate inventory of carbon stocks and the capacity of forest to accumulate carbon was emphasised at the Helsinki (1993) and Kyoto (1997) conferences [6, 24].

Dixon et al. (1994) [13] noted that the distribution of carbon stocks is very heterogeneous in terrestrial ecosystems. To obtain viable estimates at the forest scale, it is advisable to begin at a local scale (forest stand), and then to extrapolate the data using statistical analyses and pre-existing soil and stand maps.

\footnotetext{
* Corresponding author: nys@ nancy.inra.fr
} 
In this paper, the carbon stocks at the whole forest massif scale were estimated, using a method relating point estimates to existing maps $[29,44,49]$. The carbon stocks were measured in the soil, humus and vegetation components, at sampling points distributed throughout the forest massif, and then the data were extrapolated to the forest massif scale and indicators of variability calculated.

\section{MATERIALS AND METHODS}

\subsection{Experimental site characteristics}

Fougères state forest is situated in the north-east of Brittany (France) ( $\left.48^{\circ} 23^{\prime} 4 \_56^{\prime \prime}, 1^{\circ} 8 \_10^{\prime} 50^{\prime \prime}\right)$. The whole forest, which covers an area of about 1660 ha, is dominantly beech (Fagus sylvatica L.) managed as even-aged high forest stands. It was classified as an Experimental Research Observatory (O.R.E.) in 2003, the aim of which is to study the way the entire beech ecosystem functions.

The temperate oceanic climate is characterised by a moderate temperature range of $12.9^{\circ} \mathrm{C}$ and a mean annual precipitation of $868 \mathrm{~mm}$ [28]. The soils have developed in thick aeolian silt overlying autochthonous granitic sand (Vire granite), except for 50 ha in the south where the silt overlies Brioverian slate [49].

The forest is dominantly beech $(75 \%)$ together with pedunculate oak (Quercus robur L.), sweet chestnut (Castanea sativa Mill.) or birch (Betula pubescens Ehrh.) [28]. The conifers, mainly pines (Pinus sylvestris L. and Pinus laricio Poir.), fir (Abies alba Mill.) and spruce (Picea abies (L.) Karst.), are present in small sparse patches covering $5 \%$ of the forest. The storms in December 1999 caused much damage and destroyed nearly 300 ha.

\subsection{Sampling system}

Three factors influence the variations in carbon stocks: soil hydrology, stand type and age $[15,34,49]$. The sampling system was based on the ONF forest stand map, and also the 1/15000 soil map [49]. Six independent sampling classes were established using these maps: class 1 - contained trees up to 15 years old, including regenerating plots and areas affected by the 1999 storms; class $2-15$ to 60 years old; class 3-60 to 90 years old; class 4 - older than 90 years old. Coniferous trees were allocated a single age class (class 5) because different age classes could not be distinguished due to the small areas covered by these species; and one class was created for the hydromorphic areas (class 6) which occupy 9\% of the forest.

Hundred points were sampled throughout the forest, and carbon stocks were measured in the soils and the humus; they were calculated from biomass models for the vegetation. There were 20 points for each broadleaved age classes, 10 points for the coniferous stands and 10 for the hydromorphic areas. Within each class the points were selected using a stratified random sampling design on a grid of $200 \mathrm{~m}$ squares, identified in the field using a GPS, which was accurate to 1 to $25 \mathrm{~m}$ depending on the forest cover. All field sampling was carried out between April and June 2003.

\subsection{Methods of determining the carbon stocks at each sampling point}

\subsubsection{Determination of the C stocks in the soil}

The stocks in the soil were determined to a depth of $90 \mathrm{~cm}$. At each sampling point, soil samples were taken from 7 levels $(0-5 \mathrm{~cm}, 5-$ $15 \mathrm{~cm}$, and then every $15 \mathrm{~cm}$ down to $90 \mathrm{~cm}$ ) using a soil corer. To allow for the variability in the $0-5 \mathrm{~cm}$ and $5-15 \mathrm{~cm}$ horizons, four additional samples were taken for these two layers within a $5 \mathrm{~m}$ radius to provide a composite sample. The soil samples were dried for several days, at a maximum of $40^{\circ} \mathrm{C}$ in a ventilated oven, then sieved to $2 \mathrm{~mm}$ and ground in a ball or ring mill to obtain a homogeneous particle size before being analysed for $\mathrm{C}$ and $\mathrm{N}$ by combustion using a carbon nitrogen elemental analyser (CHN: NCS2500, ThermoQuest). The density of the horizons was estimated using a statistical model giving the density in relation to the carbon content, stone content $(>2 \mathrm{~mm})$ and percentage of sand [3]. The stone content throughout the forest was zero and the sand content was about 30\% [49]. The carbon stock at a sampling point was the sum of the stocks at each sampling level, derived from the product of the carbon content (in $\mathrm{gC} / \mathrm{kg}$ ) multiplied by the density (in $\mathrm{kg} / \mathrm{dm}^{3}$ ) and the layer thickness (in $\mathrm{cm}$ ).

\subsubsection{Determination of carbon stocks in the humus}

The organic horizons were sampled by taking the entire horizon present in a $0.1 \mathrm{~m}^{2}$ quadrat placed at the central point, but also in 4 replicate quadrats situated within a radius of $5 \mathrm{~m}$. At each sampling point, the thickness of the different humus layers was measured in the sampling quadrats. These thicknesses and the horizon succession at each point were then used to characterise the humus type per point using the classification suggested by Jabiol et al. [23].

The samples were oven dried separately at $65^{\circ} \mathrm{C}$ to constant weight (dry weight, $\mathrm{kg} / \mathrm{m}^{2}$ ). The 5 samples were mixed and about $1 \mathrm{~L}$ was ground to about $4 \mathrm{~mm}$ to reduce the size of large pieces. The roots were removed. Then $50 \mathrm{~mL}$ were ground in a ring grinder to produce a fine powder with a particle size of about $1 \mu \mathrm{m}$. This powder was analysed by a $\mathrm{CHN}$ to determine the total organic carbon (in $\mathrm{gC} / \mathrm{kg}$ ) which was then multiplied by the dry weight to obtain the carbon stock (in $\mathrm{kgC} / \mathrm{m}^{2}$ ).

\subsubsection{Determination of carbon stocks in the vegetation}

Carbon stocks in the vegetation were estimated by determining the phytomass. For this, three sub-components were identified: the woody biomass, under-storey vegetation and dead wood.

To determine the woody biomass at each sampling point, the inventory area was adjusted according to the tree density of each sampling class. The area of the circle was chosen so that 10 to 25 trees were measured [20]. A radius of $2 \mathrm{~m}$ was used for class $1,5 \mathrm{~m}$ for classes 2 and $6,10 \mathrm{~m}$ for classes 3 and 5 , and $15 \mathrm{~m}$ for class 4 . The $\mathrm{C} 1.30 \mathrm{~m}$ (trunk circumference at breast height, $1.3 \mathrm{~m}$ ) of all the trees and shrubs was measured [45], in addition to the collar circumference of the willow (Salix sp.) and holly (Ilex aquifolium L.) less than $1.3 \mathrm{~m}$ high as the biomass conversion for these species used this measurement $[5,19]$.

For more than $95 \%$ of the trees, the biomass of each individual was obtained using regression equations established for the site. The equations were defined for each species, defined circumference ranges and given ages. For the other 5\%, the biomass was calculated using equations published in the literature, relating circumference to dry matter [20] and it was necessary to extrapolate them to local site conditions. The references used for each species, together with the extrapolations are given in Table I. Among the available references, there were no equations available for less than $0.1 \%$ of the recorded trees. In these cases, the species which was the most similar in terms of morphology, growth, and wood density, and for which the regression equation was available in the literature, was chosen. When the circumference values measured were smaller than the minimum for $\mathrm{C} 130$, it was supposed that the species were in a development phase in which the growth curve had not yet reached a plateau, and so it was possible to extrapolate the equations.

For the under-storey vegetation, the percentage cover of the species present was determined for each inventory circle. The conversion of this cover into carbon biomass was possible for the ivy (Hedera helix L.) [19] and the biomass was considered negligible for other species. 
Table I. Summary of the references used to determine the woody biomass.

\begin{tabular}{|c|c|c|c|}
\hline Species & References used & Reason for extrapolation & Means of extrapolation \\
\hline Abies alba Mill. & Ter-Mikaelian and Korzukhin, 1997 [47] & Species & Abies balsamea (L.) Mill. \\
\hline Alnus glutinosa (L.) Gaertn. & Ter-Mikaelian and Korzukhin, 1997 [47] & $\begin{array}{l}\text { Species } \\
\text { Low C130 }\end{array}$ & Alnus rubra Bong. \\
\hline Betula pubescens Ehrh. & Ranger et al., 1981 [42] & $\begin{array}{l}\text { Species } \\
\text { High C130 }\end{array}$ & Betula pendula Roth. \\
\hline Castanea sativa Mill. & Huet et al., 2004 [20] & Species & Quercus robur $\mathrm{L}$. \\
\hline Fagus sylvatica $\mathrm{L}$. & Huet et al., 2004 [20] & High C130 & \\
\hline Frangula alnus Mill. & Ranger et al., 1981 [42] & High C130 & \\
\hline Fraxinus excelsior $\mathrm{L}$. & $\begin{array}{l}\text { Le Goff et al., } 2004 \text { [31] } \\
\text { Van de Walle et al., 2001 [51] }\end{array}$ & $\begin{array}{l}\text { Species } \\
\text { High C130 }\end{array}$ & \\
\hline Ilex aquifolium $\mathrm{L}$. & Huet, $2004[19]$ & High C130 & \\
\hline Picea abies (L.) Karst & $\begin{array}{l}\text { Jokela et al., } 1986 \text { [25] } \\
\text { Ingerslev et al., } 1999 \text { [22] }\end{array}$ & $\begin{array}{l}\text { Low C130 } \\
\text { High C130 }\end{array}$ & \\
\hline $\begin{array}{l}\text { Pinus laricio Poir. var. } \\
\text { corsicana } \text { Hyl. }\end{array}$ & Ranger, 1978 [40] & High C130 & \\
\hline Pinus sylvestris $\mathrm{L}$. & $\begin{array}{l}\text { Cermák et al., 1998, [9] } \\
\text { Porté et al., } 2002[39]\end{array}$ & Species & Pinus sylvestris and $P$. pinaster Aït. \\
\hline Populus tremula $\mathrm{L}$. & Ter-Mikaelian and Korzukhin, 1997 [47] & Species & Populus tremulö̈des Michx. \\
\hline $\begin{array}{l}\text { Pseudotsuga menziesii } \\
\text { (Mirbel) }\end{array}$ & Ponette et al., 2001 & Species & \\
\hline Quercus robur $\mathrm{L}$. & André and Ponette, 2003 [1] & Species & Quercus petraea \\
\hline Salix sp. & $\begin{array}{l}\text { Ranger et al., } 1981 \text { [42] } \\
\text { Ter-Mikaelian and Korzukhin, } 1997 \text { [47] } \\
\text { Bond-Lamberty et al., } 2002\end{array}$ & Low C130 & Sorbus aucuparia $\mathrm{L}$. \\
\hline Expansion factors & $\begin{array}{l}\text { Dupouey, } 1999[15] \\
\text { Van Camp et al., } 2004 \quad[50]\end{array}$ & & Volume towards carbon biomass \\
\hline
\end{tabular}

To determine the quantity of dead wood in each sampling area, the $\mathrm{C} 130$ of the dead trunks which were still standing were measured, and then equations were adapted as far as possible. The biomass of dead wood on the ground was derived from a volume calculation using measurements of the trunk and large branches and from wood density references [17, 20, 51].

Finally, carbon stocks in the vegetation were derived from their phytomass using local or generic equations. Mean concentrations of carbon in beech trees in Fougères forest were estimated to be $485 \pm$ $15 \mathrm{gC} / \mathrm{kg}$ of dry weight [19]. For other species we used the non-specific reference value of $500 \mathrm{gC} / \mathrm{kg}$ of dry weight $[15,21,33,51]$.

\subsection{Statistical analysis}

As the distribution of the data was not normal, we used non-parametric tests to determine the main factors explaining carbon stock variability. We used the Kruskall-Wallis statistic [36] to test for an "age effect" and the Wilcoxon-Mann-Whitney test [46] to compare pairs of sampling classes according to differences between soil types, humus types or different stands. Linear correlations were verified using Pearson's linear correlation coefficient [52]. All the statistical tests were significant at the 5\% threshold. Statistica Version 5, S-plus 6.1 and Unistat 5.2 programmes were used for the statistical analyses.

\subsection{Spatial analysis and cartography}

A carbon stock estimate was available at each sample point for the three components (soil, humus and vegetation). The point data were extrapolated to the plot scale and then to the whole forest.
In this work, Fougères forest was divided into supposedly homogeneous units which were the sampling classes. The statistical analyses tested the differences between the stocks of these 6 classes, two at a time, by group. If they were significant they were retained, if not, they were regrouped. Each new class had a corresponding stock of carbon (in $\mathrm{tC} / \mathrm{ha}$ ).

The median was used as the representative value of the stock in each class although there was little difference between the mean and the median stock value for the humus $(<5 \mathrm{tC} / \mathrm{ha})$ and the soils $(<10 \mathrm{tC} / \mathrm{ha})$. For the vegetation, the difference between the two values for a given class could be up to $40 \mathrm{tC} / \mathrm{ha}$. The median of the stocks was low and seemed to underestimate the value slightly in relation to the range of the values, while the mean value was often high, giving an over-estimate, due to the strong influence of a few extreme values, so use of the median was preferred. However, due to the wide variation in the vegetation stocks, the differences between the mean and the median stocks as a dispersion criterion were also considered. For the humus and the soils, the difference between the upper and lower quartiles of the stocks was used as a dispersion criterion.

The intersections of the ONF forest plots with the hydromorphic areas [49] were used to delineate units, each of which was defined by a sampling class. The stock in $\mathrm{tC} /$ ha was multiplied by the area of the plots to obtain the stock of $\mathrm{tC}$ in the three components: soil, humus and vegetation. The total stock, in $\mathrm{tC}$, for the whole of Fougères forest was therefore the sum of the stocks in all the plots. Then the range of the total stock was calculated and the corresponding map was drawn by GIS (Arcinfo 8.2, 2003).

Quantification of the errors related to the estimation of stocks was also studied using a Monte-Carlo simulation approach [8] with the 


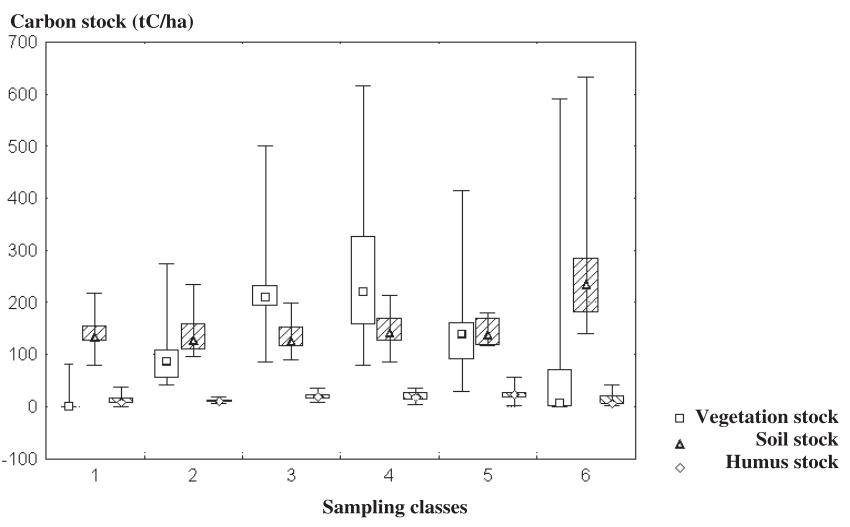

Figure 1. Statistics of the carbon stocks in the three components (soil, humus and vegetation) by sampling class (in tC/ha), with the median as the central point (class $1=$ broad-leaved, $0-15$ years old; $2=$ broadleaved, $15-60$ years old; $3=$ broad-leaved, $60-90$ years old $4=$ broadleaved, $>90$ years old; $5=$ coniferous; $6=$ hydromorphic zones).

software @Risk version 4.4 (Palisade Decision, 2003). The principle is based on a simulation relationship between parameters entered into the model respecting the distribution laws for each parameter.

\section{RESULTS}

\subsection{Carbon stocks in the ecosystem components}

Figure 1 shows that the stocks in the humus and the soil were relatively similar in the sampling classes (between 0 and $50 \mathrm{tC} / \mathrm{ha}$ in the humus and from 100 to more than $200 \mathrm{tC} / \mathrm{ha}$ in the soils), except for the hydromorphic soils in class 6 , which were very rich in carbon. The vegetation was the group which showed the greatest variation in stocks, with values ranging from 0 to more than $600 \mathrm{tC} / \mathrm{ha}$, and this variation was found in all the sampling classes. An even larger variation in vegetation stocks was observed in the hydromorphic zones and the young stands. This could be explained by the fact that the hydromorphic zones were defined using the soil map and so the vegetation at the sampling points might be very different. In the young stands, the wide variation in stocks was due to the position of the sampling points which were situated in stands affected by the 1999 storm, where the quantities of dead wood were still very large.

Figure 2 shows that the total stock of carbon per hectare was highest in the oldest stands (classes $3+4$ ). The soil stocks were relatively constant in classes 1 to 5 . The hydromorphic zones (class 6) were exceptional in that the carbon stocks in the soil were much higher than those in the vegetation or the humus, with one profile nearly 40 times higher. In addition, the statistical analyses showed that the main factor influencing the variability of the carbon stocks in the soil was its hydromorphic nature and that the stock in the soil was almost entirely independent from those in the humus and the vegetation $\left(R^{2}=0.00\right.$ and $R^{2}=0.01$ ).

Analysis of the levels of carbon stocks in the soil, depending on depth was made using the profiles, and 4 types were distinguished (Fig. 3). Profile types 1 and 2, showing an exponential decrease in carbon, represented $85 \%$ of the sampling points and

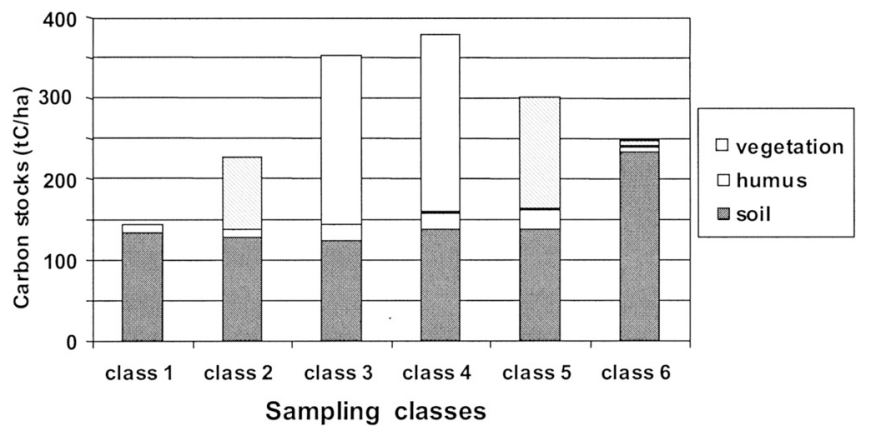

Figure 2. Median carbon stocks in each component (soil, humus and vegetation), by sampling class (in tC/ha).
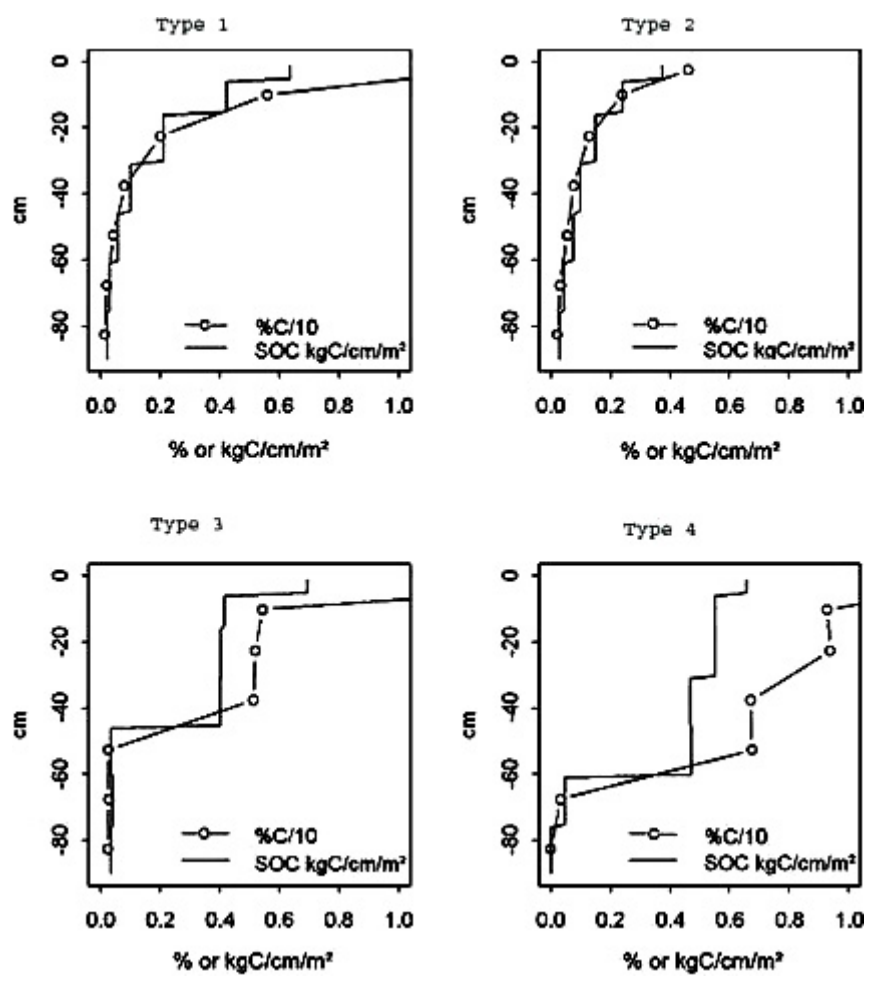

Figure 3. The 4 types of carbon stock distribution in the soil profile.

were found in all the classes. Type 1 corresponded to Dystric Cambisols and Luvisols [53] (WRB, 1998) which were well drained or had signs of hydromorphy from $40 \mathrm{~cm}$. Type 2 was found in more hydromorphic variants of the same types of soils. Most of the points with coniferous trees showed a type 2 decrease. Type 3 was only represented by 7 points where carbon levels remained homogeneous down to $40 \mathrm{~cm}$. This was due to a thicker A horizon resulting from previous cultivation. Finally, only 5 points showed profiles with very high carbon levels down to $60 \mathrm{~cm}$ (type 4). This profile type was observed for very hydromorphic soils with a deep A horizon or an accumulation of peat. Only class 6 sites exhibited this type of profile. 
Table II. Statistics of the levels and carbon stocks depending on humus type.

\begin{tabular}{lccccc}
\hline \multirow{2}{*}{ Humus type } & Number of samples & \multicolumn{2}{c}{$\begin{array}{c}\text { Carbon content } \\
(\mathrm{gC} / \mathrm{kg})\end{array}$} & \multicolumn{2}{c}{$\begin{array}{c}\text { Carbon stock } \\
\text { (tC/ha) }\end{array}$} \\
\cline { 3 - 6 } & & Median & Interquartile & Median & Interquartile \\
\cline { 3 - 6 } Hemimoder & 6 & 390 & 110 & 7 & 24 \\
Dysmoder & 74 & 387 & 93 & 16 & 15 \\
Mor & 9 & 389 & 140 & 3 & 3 \\
Hydromoder & 4 & 379 & 120 & 23 & 30 \\
Hydromull & 5 & 395 & - & 57 & - \\
Anmor & 1 & 427 & & 30 & \\
\hline
\end{tabular}

Table III. Median carbon stock by component and by sampling class.

\begin{tabular}{|c|c|c|c|c|c|c|c|c|c|}
\hline \multirow{2}{*}{ Class } & \multirow{2}{*}{ Area (ha) } & \multicolumn{2}{|c|}{ Soil } & \multicolumn{2}{|c|}{ Humus } & \multicolumn{2}{|c|}{ Vegetation } & \multicolumn{2}{|c|}{ Total } \\
\hline & & $\begin{array}{l}\text { Median stock } \\
(\mathrm{tC} / \mathrm{ha})\end{array}$ & $\begin{array}{c}\text { Dispersion } \\
\text { index }(\mathrm{tC} / \mathrm{ha})\end{array}$ & $\begin{array}{l}\text { Median stock } \\
\text { (tC/ha) }\end{array}$ & $\begin{array}{c}\text { Dispersion } \\
\text { index (tC/ha) }\end{array}$ & $\begin{array}{l}\text { Median stock } \\
(\mathrm{tC} / \mathrm{ha})\end{array}$ & $\begin{array}{c}\text { Dispersion } \\
\text { index }(\mathrm{t} C / \mathrm{ha})\end{array}$ & $\begin{array}{c}\text { Median stock } \\
\text { (tC/ha) }\end{array}$ & $\begin{array}{c}\text { Dispersion } \\
\text { index }(\mathrm{tC} / \mathrm{ha})\end{array}$ \\
\hline 1 & 289.3 & $134.3^{\mathrm{a}}$ & 40.7 & $9.2^{\mathrm{a}}$ & 11.9 & $0.04^{\mathrm{a}}$ & 38.9 & 143.8 & 46.0 \\
\hline 2 & 329.3 & $128.2^{\mathrm{a}}$ & 50.0 & $10.8^{\mathrm{a}}$ & 4.4 & $86.7^{\mathrm{b}}$ & 7.5 & 230.5 & 14.6 \\
\hline 3 & 257.6 & $124.8^{\mathrm{a}}$ & 39.3 & $18.4^{\mathrm{b}}$ & 9.0 & $209.1^{\mathrm{c}}$ & 6.7 & 361.4 & 14.1 \\
\hline 4 & 463.3 & $138.8^{\mathrm{a}}$ & 45.0 & $18.7^{\mathrm{b}}$ & 15.5 & $220.7^{d}$ & 29.5 & 373.0 & 36.9 \\
\hline 5 & 86.8 & $138.2^{\mathrm{a}}$ & 52.3 & $22.9^{\mathrm{b}}$ & 9.6 & $139.2^{\mathrm{e}}$ & 22.8 & 291.5 & 30.2 \\
\hline 6 & 139.2 & $234.2^{\mathrm{b}}$ & 104.5 & $5.4^{\mathrm{c}}$ & 31.5 & $6.8^{\mathrm{f}}$ & 86.7 & 246.6 & 131.4 \\
\hline Forest & $1565.5^{*}$ & 136.2 & 8.9 & 14.6 & 8.9 & 112.9 & 164.8 & 269.1 & 109.4 \\
\hline
\end{tabular}

The dispersion index corresponds to the interquartile for soil and humus, and the difference between mean and median stock for the vegetation and the total stock. The index letters within a column indicate a significant difference using the Wilcoxon-Mann-Whitney test at the 5\% threshold. Class $1=$ broad-leaved, $0-15$ years old; $2=$ broad-leaved, $15-60$ years old; $3=$ broad-leaved, $60-90$ years old; $4=$ broad-leaved, $>90$ years old; $5=$ coniferous; $6=$ hydromorphic zones).

* In total 1699 ha, the difference is due to the non forested zones (houses, cultivated plots ...).

Figure 2 shows that the stocks in the humus represent a relatively low and constant percentage of the total stock. The median carbon values were very close (in the order of $380 \mathrm{~g} / \mathrm{kg}$ ), whatever the humus type considered (Tab. II). Statistically, there was no significant difference between the stocks of the different humus types, except for the stocks in the hemimoder and the dysmoder $(P=0.03)$. Conversely, the vegetation (stock, nature and age) growing on these holorganic horizons was the principal factor in the variability of these stocks.

Regarding the vegetation, the wide differences between the classes can be seen clearly in Figure 2 . In the young stands, the vegetation was mainly concentrated in the shrub and herb layers, which explained the nearly zero stock. Conversely, in classes 3 and 4, most of the carbon stocks were concentrated in the large trees, and this was accentuated by the large areas covered by these classes. The increase rate in the carbon stocks seemed to be less abrupt between the high forest stages (classes 3 and 4) because of the thinning which had been carried out. This emphasises the importance of forest management. The influence of stand age was shown in the broad-leaved age classes and seemed to be more discriminant than their nature (broad-leaved or coniferous). The statistical comparison between the carbon stocks of the different stands did not show any significant result. The stocks in the humus of the coniferous stands (class 5) were higher than those of the other classes, but the stocks in the vegetation were also high showing that conifers can accumulate large quantities of carbon. Even if trees only represent half of the total stock, stocks in the vegetation have a strong influence on the variability $\left(R^{2}=0.81\right)$ due to management practices.

\subsection{Amalgamation in group of homogeneous classes}

Table III shows that, for the stocks in the soil, only class 6 was significantly different from the others. So, two groups were kept for the cartography: group I was an amalgamation of classes 1 to 5 and group II represented class 6 . For the humus, three groups could be distinguished: classes 1 and 2, classes 3, 4 and 5, and class 6. These three groups, named group A (mull), $\mathrm{B}$ (moder) and $\mathrm{C}$ (hydromull) respectively, were used to map the humus stocks. For the vegetation, all the sampling classes were significantly different from each other, except for classes 3 and 4. When mapping the vegetation stocks, all the classes were retained.

\subsection{Carbon stocks in the whole forest}

The maps of the median stocks by group (in tC/ha) and their variability are represented in Figures 4 and 5. The maps of the stocks in the soil only separated the hydromorphic zones, 
(a)

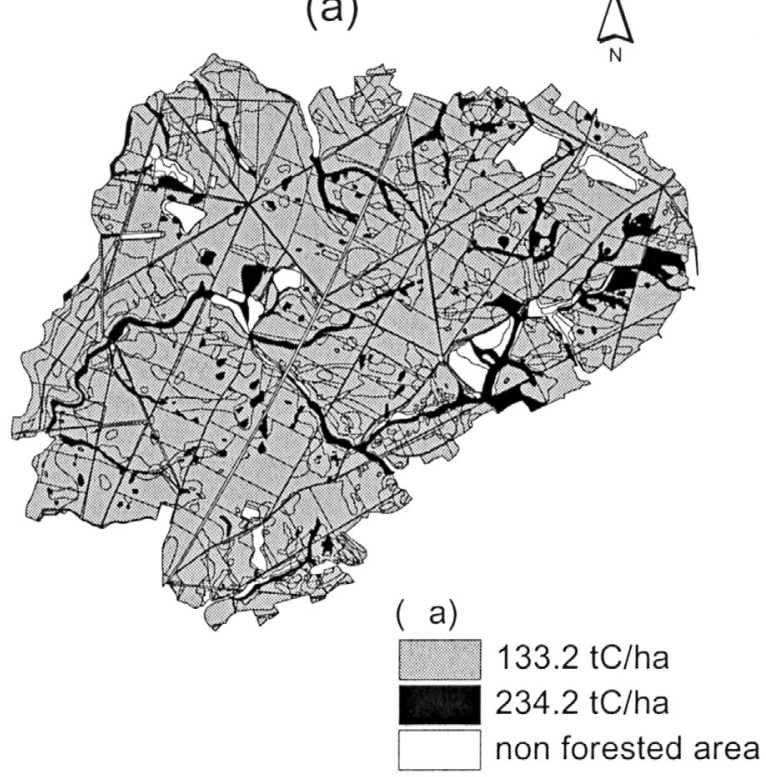

(c)

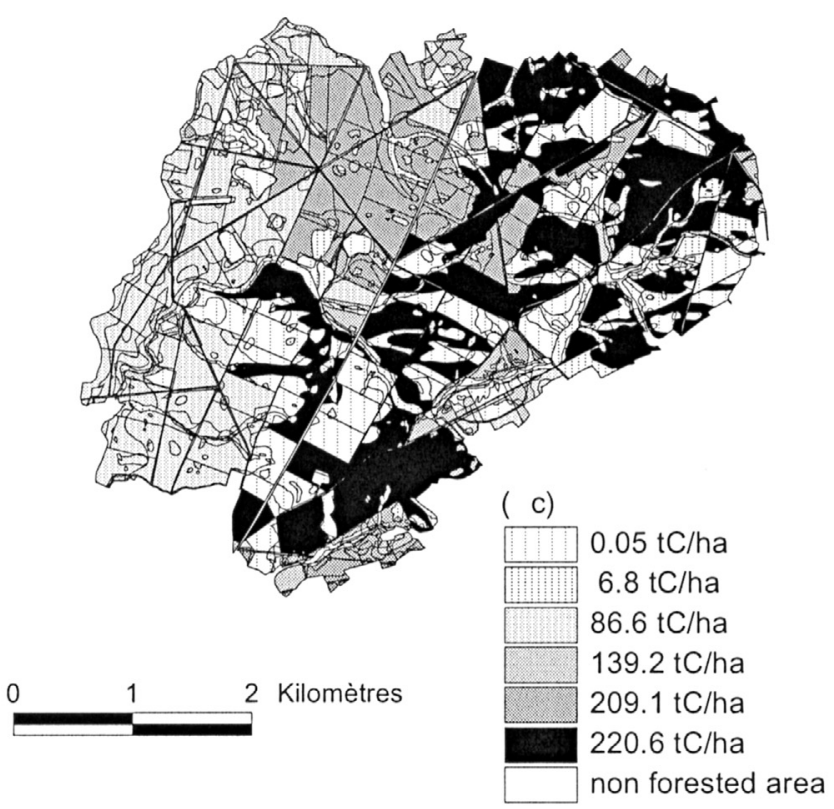

(b)

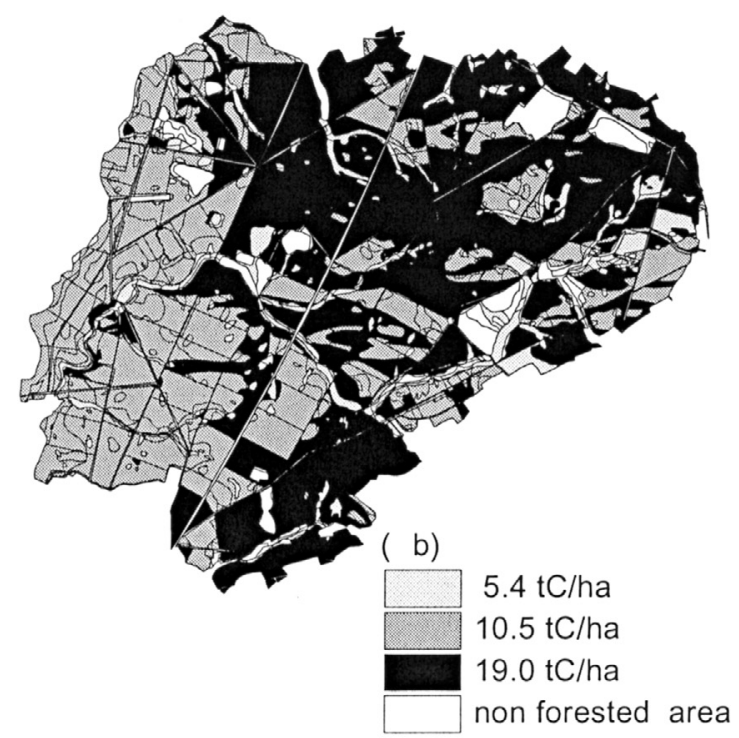

(d)

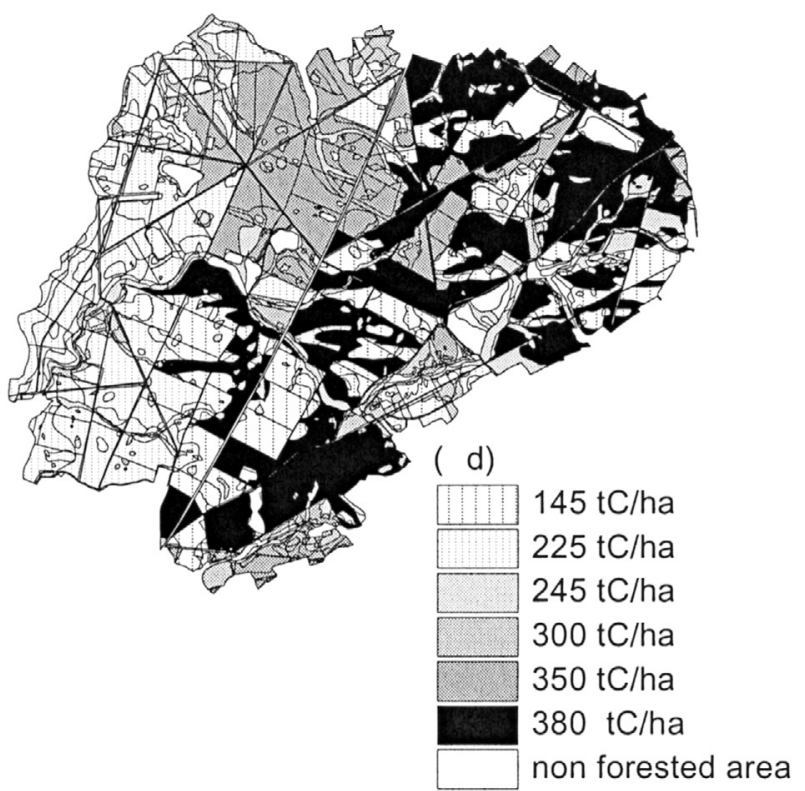

Figure 4. Maps of the median stocks by group (in tC/ha) for the soil (a), the humus (b), the vegetation (c) and the ecosystem (d).

characterised by very high median stocks ( $234 \mathrm{tC} / \mathrm{ha}$ ) but which were also very variable with an interquartile of the stocks of $103 \mathrm{tC} / \mathrm{ha}$. For the whole forest, the soils contained about half of the carbon stocks $(50.2 \%)$ with a total variation between 222000 and $239000 \mathrm{tC}$. The hydromorphic zones only represented a small part of the stock due to their limited area in the forest. It should also be noted that $68 \%$ of the carbon stocks in the soil were located in the upper $30 \mathrm{~cm}$ of the profile.
For the humus, the values were lowest in group $\mathrm{C}$, just above $5 \mathrm{tC} /$ ha, and reached nearly $20 \mathrm{tC} /$ ha in group B. The interquartile map showed that the data range was lower in group $\mathrm{A}$ (7.9 tC/ha) while group B had the highest interquartile values (11.3 tC/ha). The maps demonstrate a spatial structure characterised by lower, less variable stocks in the west of the forest, due to the distribution of the age classes (the stands were younger in the west). The humus held a total stock of 22000 

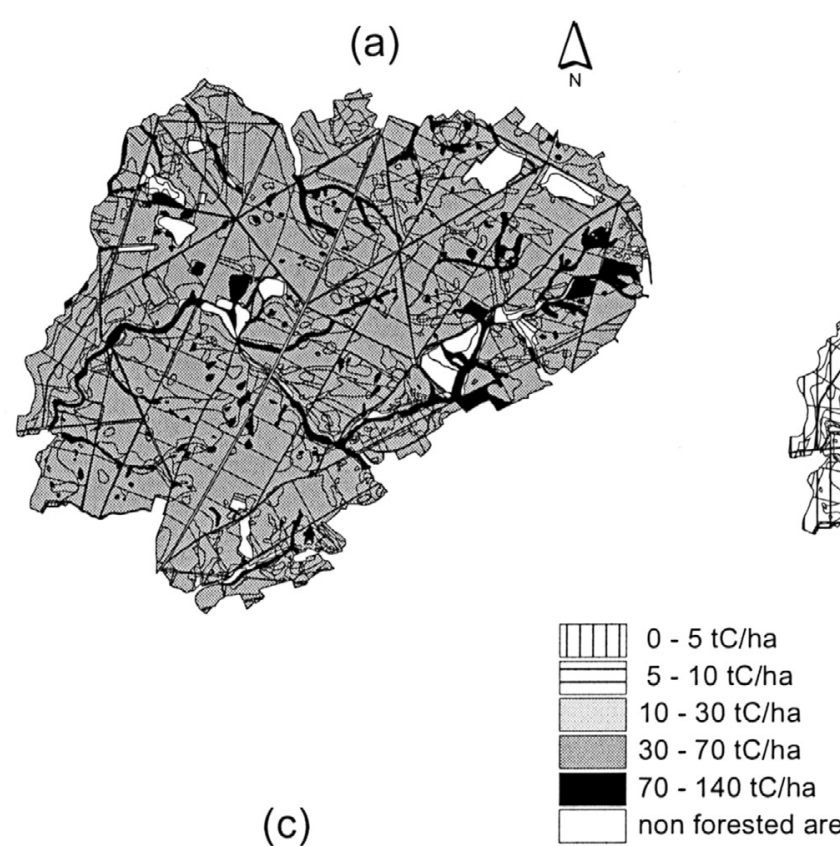

(b)

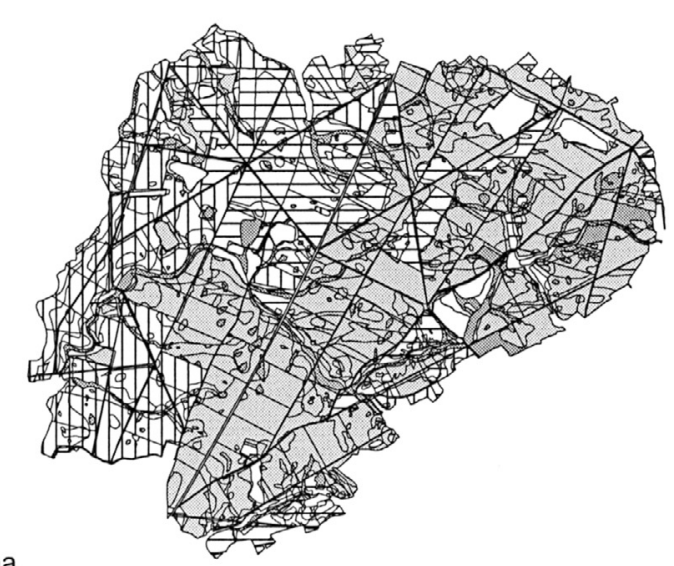

(c)
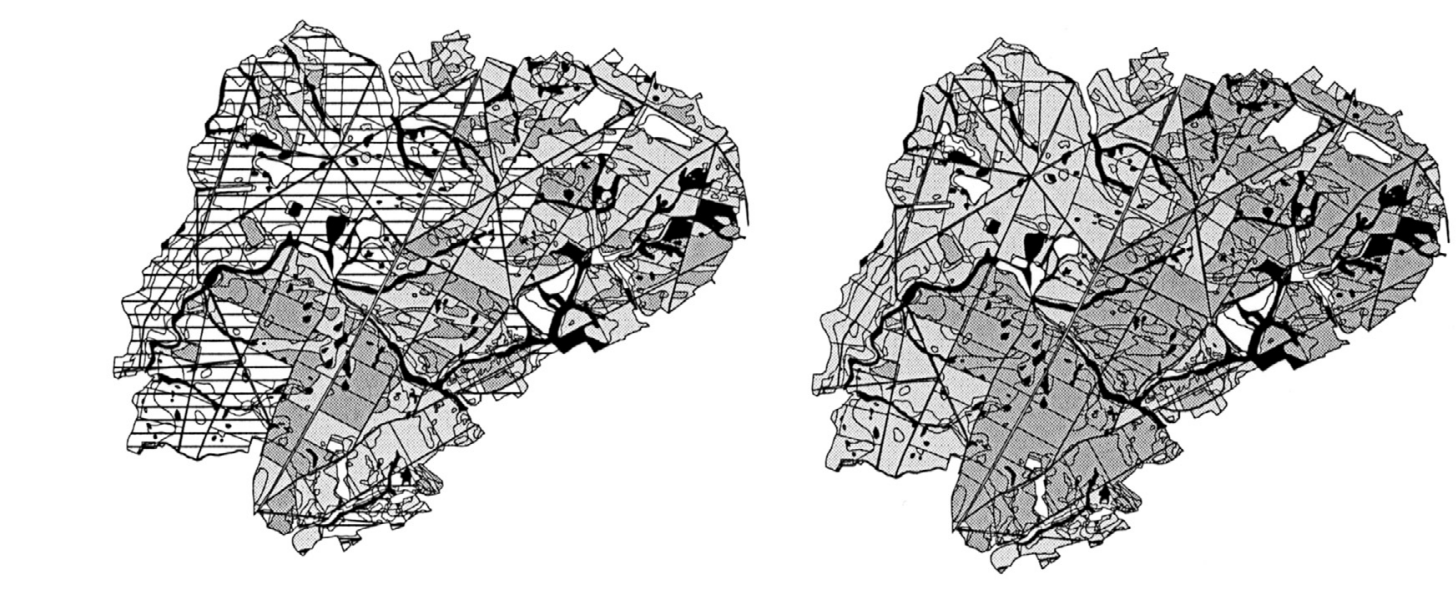

(d)

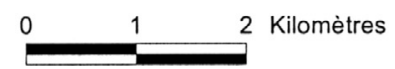

Figure 5. Dispersion index of the carbon stocks by group (in $t C /$ ha) for the soil (a), the humus (b), the vegetation (c) and the ecosystem (d). The dispersion index corresponds to the interquartile for soil and humus, and the difference between mean and median stock for the vegetation and the total stock.

to $25000 \mathrm{tC}$, representing $5 \%$ of the total stock of the whole forest and nearly $10 \%$ of the carbon stock in the soil.

In the vegetation, the carbon stocks per hectare were highest in class 4 (220.7 tC/ha) and lowest in class 1 (0.04 tC/ha). In terms of divergence (the difference between the mean and the median), the least variable were classes 2 and 3 , with divergence values of 6.7 and $7.5 \mathrm{tC} /$ ha respectively, while class 6 was the most heterogeneous ( $86.7 \mathrm{tC} / \mathrm{ha})$. For the whole forest, the vegetation represented just under half of the carbon stocks (44.7\%), corresponding to a stock between 198000 and $241000 \mathrm{tC}$. The maps of the total stocks were highly correlated to those of the vegetation because the class with the lowest stocks was also class 1 (144 tC/ha) and those with the highest stocks were also classes 3 and 4 (361 and 373 tC/ha respectively). In terms of divergence, the most homogeneous were classes 2 and 3, with a divergence index of $14 \mathrm{tC} /$ ha in class 2 , whereas class 6 was more variable $(131 \mathrm{tC} / \mathrm{ha})$. This confirmed the strong influence of vegetation on the total stocks in Fougères forest. Using the surface of each class, the total carbon stock was estimated to be between $442000 \mathrm{tC}$ and $505150 \mathrm{tC}$ for the whole of Fougères forest, which is equivalent to a total mean stock per hectare of between 283 and $323 \mathrm{tC} / \mathrm{ha}$. The spread between the two extremes of this estimated range was in the order of $15 \%$. 


\section{DISCUSSION}

\subsection{Carbon stocks in the ecosystem components}

At the whole forest scale, the proportions in relation to the total stock, $50 \%$ in the soil, $5 \%$ in the humus and $45 \%$ in the vegetation, were comparable with the data obtained by Dupouey et al. [15] (1999) for French forests (51\% in the soil, 6\% in the humus and $43 \%$ in the vegetation). Within temperate forest ecosystems, carbon is found mainly in the soil (50 to $70 \%$ of the total carbon), and some authors suggest that the stocks in this component will increase with time due to anthropic carbon and nitrogen fertilization [12, 24, 33, 51]. However, quantities of carbon in the soil are fairly variable under the influence of natural or man-made effects. In temperate climates, the $0-30 \mathrm{~cm}$ horizon is supposed to contain more than $80 \%$ of the carbon whereas humus only represents a small proportion of the stocks likely to evolve rapidly due to the effect of forestry practices [2].

However, the values of the stocks obtained in Fougères forest were much higher than those of the latter authors. For the French forest soils, values of $79 \mathrm{tC} /$ ha were obtained, and only $44 \mathrm{tC} /$ ha in Belgian broadleaf forests [32] while the stocks in Fougères were about $142 \mathrm{tC} / \mathrm{ha}$. The forest of Fougères has been exploited as forest (for wood and hunting) for several centuries and so it has very deep loamy soils with carbon levels and densities which are higher than elsewhere. Therefore, the $0-30 \mathrm{~cm}$ horizon stocks $99 \mathrm{t} / \mathrm{ha}$ of carbon whereas stocks calculated for all French forests were about $70 \mathrm{tC} /$ ha [43]. Moreover, significant carbon stocks were measured at depths $>30 \mathrm{~cm}$ representing more than $30 \%$ of the total carbon stock in the soil.

The carbon stocks in the humus of 14 to $16 \mathrm{tC} / \mathrm{ha}$, were fairly high compared with those found in other work: $9 \mathrm{tC} / \mathrm{ha}$ in French forests according to Dupouey et al. (1999) [15] and $12 \mathrm{tC} / \mathrm{ha}$ in English forests according to Thornley and Cannell (1996) [48]. The nature of the soil substrate and its influence on organic matter turnover may explain this. Most French forests occur on non-acidic substrates where mineralization is faster than in the context of English forests, mainly localised on acid substrates [4]. Consequently, carbon stocks are fairly low in most French forests, but Fougères forest, situated on a poor substrate has very acid soils and thus stocks which are higher than the national mean.

The stocks in the vegetation reached $126 \mathrm{tC} / \mathrm{ha}$ in Fougères forest compared with $59 \mathrm{tC} /$ ha in French forests. One explanation for this considerable difference could be the high proportion of beech trees in the forest $(60 \%$ of the standing trees, but $80 \%$ of the total woody biomass) as beech accumulates more carbon than other species [51]. This is accentuated by the fact that Fougères forest has been managed as a regular high forest since the middle-ages, so it is fairly old relative to other forests, and thus it contains more carbon due to the lack of mineralization by cultivation. Nevertheless, it remains difficult to compare carbon stocks in the vegetation, because the biomass of a species varies from one stand to another, depending on the geographical conditions [20]. Janssens et al. (1999) [24] emphasised the importance of soil fertility, stage of development and forestry management on growth and biomass allocations. The vegetation may contain between 23 to $82 \%$ of the total ecosystem carbon, three quarters of which are in the woody parts [12, $16,35]$. The rooting system may also contain a large proportion of the carbon, in the order of a quarter of the stocks in the vegetation $[14,41]$. Variations in the stocks in the vegetation depend on the age and nature of the stands but also on natural disturbances (fires, storms) or artificial ones like forestry practices $[15,27,34,37]$.

\subsection{Sources of error and accuracy of the estimate}

The study at the whole forest scale provided an estimate of carbon stock uncertainty. This estimate integrated the possible sources of error related to the different phases of fieldwork but also to the scale change.

For the soils and the humus, errors linked to sampling and analyses remained relatively small. The main source of uncertainty lay in the use of the model estimating bulk density for which the mean error, obtained by comparing the results of the model with the density measurements made at the sampling points in Fougères forest, is $-0.07 \mathrm{~g} / \mathrm{cm}^{3}$, thus indicating a slight underestimation.

Conversely, for the vegetation, even if errors in the field measurements were low, the conversion to dry matter and carbon stocks of these measurements reduced the accuracy. The main uncertainty was due to the use of regression equations and the extrapolations made relative to the initial conditions. The empirical nature of the equations meant that they were not totally accurate [5]. Also, for 5\% of the forest stands, in the conversion of dry matter into carbon there was an error of $\pm 50 \mathrm{~g} \mathrm{C} / \mathrm{kg}$ of dry matter [15]. The questionable choice of extrapolating certain equations was justified by the fact that only $2 \%$ of the carbon stocks in the woody biomass were concerned by these extrapolations relative to the species and less than $5 \%$ relative to geographical conditions.

Several sources of error occurred in the evaluation of the biomass of the under-storey. They were due to the wide spatial heterogeneity controlled by distribution laws which were more complex than those of the stands. Nevertheless this biomass could be considered as insignificant in terms of the carbon stock (less than $3 \%$ of the stocks) especially as the holly, representing nearly $99 \%$ of the under-storey biomass in the old high-forest [19] was included in the woody biomass.

The determination of the quantity of dead wood at the sampling points included an error linked to the absence of data. However, contrary to the under-storey vegetation, it represented a significant quantity of carbon stocks. The sampling method using litter collectors did not include sufficient quantities of large pieces of wood. In our work, only a complete harvest within the sampling circle gave accurate results, but this was difficult in practice due to the high spatial variation and the origin of the material [28]. To have local data, Fíner et al. (2003) [17] suggested that dead wood less than $5 \mathrm{~cm}$ diameter should be collected in the quadrats, and then weighed after drying, to convert this quantity into carbon. Wood with a diameter greater than $5 \mathrm{~cm}$ should be measured to calculate its volume and then its dry weight. Coomes et al. (2002) [10] added that it might be interesting to choose the density of the wood depending on the stage of decomposition.

A Monte Carlo's simulation was used to try to quantify the accuracy of these results. An analysis of the inaccuracies in the levels of stocks in the vegetation could not be carried out due to the lack of sufficient information about the prediction models 
of the carbon stocks for each tree as a function of the biomass. For the soils, it was possible to identify the principal sources of error and evaluate the associated uncertainty. Monte-Carlo's approach showed that carbon stocks in the soil varied within a range of $22 \mathrm{tC} / \mathrm{ha}$; this range represented the difference between the upper and the lower deciles of the 1000 simulations used. It was also possible to examine the effect of measurement errors on the median stocks estimated by sampling class. The interdeciles were about $2.3 \mathrm{tC} /$ ha (about $2 \%$ of the median stock) for sampling classes 1 to 5, and about 19.7 tC/ha (about 20\%) for class 6 (hydromorphic soils).

The median and the mean were considered as a range, which meant that the accuracy of the total carbon stock at the forest scale was about $15 \%$. The soils and humus of the forest were relatively homogenous in form and in terms of stocks, but the natural vegetation diversity divided the forest into small units. So at the forest scale, it was this heterogeneity of the landscape mosaic which had to be foreseen by identifying the constituent elements [7]. Of these elements, some had been used to determine the sampling classes, but others had not been taken into account, for example the forest margins, clearings, or forest tracks. In addition, the intra-plot variations were too small to be included into a study of the whole forest, in spite of the fact that they included local modifications of carbon stocks which could be amplified after extrapolation. These micro variations, in particular the stands with mixtures of coniferous and broadleaved trees or the distribution of rides in the plots in class 1 , could not be integrated into the cartographic parameters. Other variations at larger scales were only partially considered, for instance the areas affected by the storms (included in class 1). However, the sampling points situated in the plots had much higher stocks than those of class 1 due to the large quantities of dead wood.

\subsection{Improvement of the estimation method at the whole forest scale}

The determination of age classes carried out using cartographic data and data in the literature was generally efficient. The choice of the 6 sampling classes was relatively accurate for the vegetation. Conversely, for the soil and the humus, the same results could have been obtained using fewer classes ( 2 for the soil and 3 for the humus). There was some uncertainty in the estimation of the stocks of carbon in the soil which were much higher in the hydromorphic zones than in the other classes. For the soils, the number of sampling classes needed to be increased in the hydromorphic zones depending on the degree of waterlogging. To characterise the vegetation division better, the number of points needed to be increased in the most heterogeneous classes, which were the very young broad-leaved class ( $0-15$ years) and the hydromorphic zones. This would have provided a better understanding of the factors causing variations in the stocks but implied an increase in the total number of points.

The scale change requires generalised models taking factors like age or site type into account. The data in the literature are still too rare to establish such models.

Finally, we retained the method combining point estimates with the maps, but other sources of information could have been used. Estimates from the national forestry inventories were simple and cheap but underestimated the underground biomass and the associated carbon stocks, and also that of the young stands ( $<30$ years old) where biomass is considered to be zero [35]. In New-Zealand, Coomes et al. (2002) [10] also used extrapolation methods but from satellite and aerial photos. In this study, these methods could have helped to characterise the heterogeneity of certain very variable classes, like the young stands, as the maps do not always correspond with the reality in the field. However, existing maps based on very detailed surveys are often more accurate and do not require initial interpretation in terms of age or species.

\section{CONCLUSION}

The estimate of the total stocks of the whole of Fougères forest produced results between 442000 and $505150 \mathrm{tC}$, that is between 282.5 and $322.7 \mathrm{tC} / \mathrm{ha}$. The spread between these two estimated extremes is about $15 \%$. The originality of this method, combining point estimates and existing maps with two successive scale changes, lies in the integration of the three components (soil, humus and vegetation) and an attempt to quantify the error, the importance of which was emphasised in the Kyoto protocol. The method proposed in this work to estimate the carbon stocks at the whole forest scale in Fougères could be applied to other situations, on the condition that the sampling classes are adapted to local factors causing variations in the stocks. The results obtained could also be included in the future management of forests, and be used to create a reference method to evaluate carbon stocks at the regional scale.

Acknowledgements: We would like to thank François Toutain for the use of his maps, and all the technicians without whom this project would not have been possible; in particular O. Quidu from Inra Rennes; S. Didier, L. Gelhaye and C. Hossann from Inra Nancy; and the students from the University of Rennes-1. This work was financed by the GIP-ECOFOR and the Office National des Forêts as one of the Environmental Research sites on "Lowland beech". The paper was translated into English by Aldyth Nys.

\section{REFERENCES}

[1] André F., Ponette Q., Comparison of biomass and nutrient content between oak (Quercus petraea) and hornbeam (Carpinus betulus) trees in a coppice-with-standards stand in Chimay (Belgium), Ann. For. Sci. 60 (2003) 489-502.

[2] Arrouays D., Deslais W., Badeau V., The carbon content of topsoil and its geographical distribution in France, Soil Use Manage. 17 (2001) 7-11.

[3] Belkacem S., Nys C., Dupouey J.L., Évaluation des stocks de carbone dans les sols forestiers : importance de la sylviculture et du milieu sur la variabilité, Rapport INRA, Nancy, 1998.

[4] Bessières F., Casagrande P., Cinotti B., Granger B., AGRESTE, La statistique agricole, Ministère de l'Agriculture et de la Pêche, Paris, 1994.

[5] Bond-Lamberty B., Wang C., Gower S., Aboveground and belowground biomass and sapwood area allometric equations for six boreal tree species of northern Manitoba, Can. J. For. Res. 32 (2002) 1441-1450.

[6] Brack C-L., Richards G-P., Carbon accounting model for forests in Australia, Environ. pollut. 116 (2002) 187-194.

[7] Burel F., Baudry J., Écologie du paysage. Concepts, méthodes et applications, Tec \& doc, Paris, 1999.

[8]Burrough P., McDonnell R., Principles of Geographical Information Systems, Oxford University Press, Oxford, 1998. 
[9] Cermák J., Riguzzi F., Ceulemans R., Scaling up from the individual tree to the stand level in Scots pine. I. Needle distribution, overall crown and root geometry, Ann. Sci. For. 55 (1998) 63-88.

[10] Coomes D., Allen R., Scott N., Goulding C., Beets P., Designing systems to monitor carbon stocks in forests and shrublands, For. Ecol. Manage. 164 (2002) 89-108.

[11] Curtis P.-S., Hanson P.-J., Bolstad P., Barford C., Randolph J.-C., Schmid H.-P., Wilson K.-B., Biometric and eddy covariance based estimates of annual carbon storage in five eastern North American deciduous forests, Agric. For. Meteorol. 113 (2002) 3-19.

[12] Dieter M., Elsasser P., Carbon stocks and carbon stock changes in the tree biomass of Germany's forests, Forstw. Cbl. 121 (2002) 195-210

[13] Dixon R.-K., Brown S., Houghton R.-A., Solomon A.-M., Trexler M.-C., Wisniewski J., Carbon pools and flux of global forest ecosystems, Science 263 (1994) 185-190.

[14] Dong J., Kaufmann R.-K., Myneni R.-B., Tucker C.-J., Kauppi P.-E., Liski J., Buermann W., Alexeyev V., Hughes M.-K., Remote sensing estimates of boreal and temperate forest woody biomass: carbon pools, sources, and sinks, Remote sens. Environ. 5789 (2002) $1-18$.

[15] Dupouey J.-L., Pignard G., Badeau V., Thimonier A., Dhôte J.-F., Nepveu G., Bergès L., Augusto L., Belkacem S., Nys C., Stocks et flux de carbone dans les forêts françaises, C. R. Acad. Agric. Fr. 85 (1999) 293-310.

[16] Duvigneaud P., La synthèse écologique, Doin, Paris, 1980.

[17] Fíner L., Mannerkoski H., Piirainen S., Starr M., Carbon and nitrogen pools in an old-growth, Norway spruce mixed forest in eastern Finland and changes associated with clear-cutting, For. Ecol. Manage. 174 (2003) 51-63.

[18] Houghton R.A., The future role of tropical forest in affecting the carbon dioxide concentration of the atmosphere, Ambio 19 (1990) 204.

[19] Huet S., Contribution à l'étude du fonctionnement carboné d'une hêtraie de plaine atlantique, incluant sa végétation de sous-bois, dans une chronoséquence, Ph.D. thesis University of Rennes 1, 2004, 370 p.

[20] Huet S., Forgeard F., Nys C., Above- and belowground distribution of dry matter and carbon biomass of Atlantic beech (Fagus sylvatica L.) in a time sequence, Ann. For. Sci. 61 (2004) 683-694.

[21] Hyvönen R., Olsson B., Lundkvist H., Staaf H., Decomposition and nutrient release from Picea abies (L.) Karst. and Pinus sylvestris L. logging residues, For. Ecol. Manage. 126 (2000) 97-112.

[22] Ingerslev M., Hallbäcken L., Above ground biomass and nutrient distribution in a limed and fertilized Norway spruce (Picea abies) plantation, Part II. Accumulation of biomass and nutrients, For. Ecol. Manage. 119 (1999) 21-38.

[23] Jabiol B., Brêthes A., Ponge J.-F., Toutain F., Brun J.-J., L'humus sous toutes ses formes, ENGREF, Nancy 1995.

[24] Janssens I.-A., Sampson D.-A., Cermak J., Meiresonne L., Riguzzi F., Overloop S., Ceulemans R., Above- and belowground phytomass and carbon storage in a Belgian Scots pine stand, Ann. For. Sci. 56 (1999) 81-90.

[25] Jokela E., Van Gurp K., Briggs R., White E., Biomass estimation equations for Norway spruce in New York, Can. J. For. Res. 16 (1986) 413-415.

[26] Kauppi P.-E., Mielikäinen K., Kuusela K., Biomass and carbon budget of European forests, 1971 to 1990, Science 256 (1992) 70-74.

[27] Kurz W.-A., Apps M.-J., A 70-year retrospective analysis of carbon fluxes in the Canadian forest sector, Ecol. Appl. 9 (1999) 526-547.

[28] Lebret M., Les humus forestiers en hêtraie de plaine : analyse des facteurs de l'évolution dans une chronoséquence, Ph.D. thesis, University of Rennes, 2002, $350 \mathrm{p}$.

[29] Lecointe S., De la parcelle forestière au massif forestier : estimation des stocks de carbone dans la biomasse végétale et dans les humus d'un massif forestier, Application à la forêt domaniale de Fougères, Master publication, ENSA Rennes, 2003.

[30] Lee J., Morrison I.-K., Leblanc J.-D., Dumas M.-T., Cameron D.-A., Carbon sequestration in trees and regrowth vegetation as affected by clearcut and partial cut harvesting in a second-growth boreal mixehood, For. Ecol. Manage. 169 (2002) 83-101.
[31] Le Goff N., Granier A., Ottorini J.-M., Peiffer M., Biomass increment and carbon balance of ash (Fraxinus excelsior) trees in an experimental stand in northeastern France, Ann. For. Sci. 61 (2004) $577-588$.

[32] Lettens S., Van Orshoven J., Van Wesemael B., Muys B., Soil organic and inorganic carbon contents of landscape units in Belgium derived using data from 1950 to 1970, Soil Use Manage. 20 (2004) $40-47$.

[33] Liski J., Perruchoud D., Karjalainen T., Increasing carbon stocks in forest soils of Western Europe, For. Ecol. Manage. 169 (2002) 159-175.

[34] Liu J., Peng C., Apps M., Dang Q., Banfield E., Kurz W., Historic carbon budgets of Ontario's forest ecosystems, For. Ecol. Manage. 169 (2002) 103-114.

[35] Malhi Y., Baldocchi D.-D., Jarvis P.-G., The carbon balance of tropical, temperate and boreal forests, Plant Cell Environ. 22 (1999) 715-740.

[36] Morin A., Findlay S., Cours de biostatistiques, Université d'Ottawa Ottawa, 2001.

[37] Nabuurs G.-J., Päivinen R., Sikkema R., Morhen G.-M.-J., The role of European forests in the global carbon cycle-A review, Biomass Bioenergy 13 (1997) 345-358.

[38] Ponette Q., Ranger J., Ottorini J.-M., Ulrich E., Aboveground biomass and nutrient content of five Douglas-fir stands in France, For. Ecol. Manage. 142 (2001) 109-127.

[39] Porté A., Trichet P., Bert D., Loustau D., Allometric relationships for branch and tree woody biomass of Maritime pine (Pinus pinaster Aït.), For. Ecol. Manage. 158 (2002) 71-83.

[40] Ranger J., Recherche sur les biomasses comparées de deux plantations de pin laricio de Corse avec ou sans fertilisation, Ann. Sci. For. 35 (1978) 93-115.

[41] Ranger J., Gelhaye D., Belowground biomass and nutrient content in a 47-year-old Douglas-fir plantation, Ann. For. Sci. 58 (2001) 423-430

[42] Ranger J., Nys C., Ranger D., Étude comparative de deux écosystèmes forestiers feuillus et résineux des Ardennes primaires françaises. I. Biomasse aérienne du taillis sous-futaie, Ann. Sci. For. 38 (1981) 259-282.

[43] Ranger J., Badeau V., Dambrine E., Dupouey J.-L., Nys C., Party J.-P., Turpault M.-P., Ulrich E., Évolution constatée des sols forestiers au cours des dernières décennies, Rev. For. Fr. 52 (2000) 49-70.

[44] Recena P., Estimation des stocks de carbone dans les sols et la litière à l'échelle d'un massif forestier, Cas du massif forestier de Fougères (Ille-et-Vilaine), Master publication, ENSA Rennes, 2003.

[45] Rondeux J., La mesure des arbres et des peuplements forestiers, Les Presses Agronomiques de Gembloux, Gembloux, 1993.

[46] Sprent P., Pratique des statistiques non paramétriques, INRA éditions, Paris, 1992.

[47] Ter-Mikaelian M.-T., Korzukhin M.-D., Biomass equations for sixty-five North American tree species, For. Ecol. Manage. 97 (1997) $1-24$

[48] Thornley J.-H., Cannell M.-G., Temperate forests responses to carbon dioxide, temperature and nitrogen: a model analysis, Plant Cell Environ. 19 (1996) 1331-1348.

[49] Toutain F., Étude du sol et des eaux de la forêt de Fougères, Ph.D. thesis, University Rennes, 1996.

[50] Van Camp N., Vande Walle I., Mertens J., De Neve S., Samson R., Lust N., Verbeeck H., Van Cleemput O., Hofman G., Carlier L., Inventory-based carbon stock of Flemish forests: a comparison of European biomass expansion factors, Ann. For. Sci. 61 (2004) 677-682.

[51] Vande Walle I., Mussche S., Samson R., Lust N., Lemeur R., The above- and belowground carbon pools of two mixed deciduous forest stands located in East-Flanders (Belgium), Ann. For. Sci. 58 (2001) 507-517.

[52] Wonnacott T., Wonnacott R., Statistique. Économie, gestion, sciences, médecine, Economica Paris, 1991.

[53] WRB, World Reference Basis for Soil Resources, FAO, ISRIC, $1998,87 \mathrm{p}$. 